\title{
Katastrofetriage - behov for en norsk standard
}

\begin{abstract}
Når ulykkesstedet er vanskelig tilgjengelig og antallet pasienter eller skadeomfanget overstiger disponibel hjelpekapasitet, vil «sortering» og prioritering av tilskadekomne være essensielt. Dette anerkjente prinsippet for katastrofehåndtering kalles «triage». Gjennom rask og presis triage kan rett pasient komme til rett sted til rett tid. Katastrofetriage innebærer at vi gjør mest mulig for flest mulig. Det finnes ikke noen nasjonal standard for dette.
\end{abstract}

Togulykken ved Åsta krevde 19 liv, 67 mennesker slapp fra hendelsen uten livstruende skader (1). Denne ulykken er dessverre ikke unik, store ulykker skjer med jevne mellomrom. Bussulykken i Verdal og skredulykken i Vassdalen er eksempler på hendelser som medførte ekstraordinær redningsinnsats.

Elementene i god katastrofehåndtering er ledelse, risikohåndtering, triage, terapi og transport. En evaluering av redningsarbeidet ved terrorbombingen av London i 2005 påviste at rask tilgang til avansert katastrofehåndtering medførte effektiv ressursbruk og bedret utfallet for pasientene (2). Videre var konklusjonen i en innsats- analyse omkring terrorangrepet på World Trade Center i 2001 at «mangel på kommunikasjon medførte mer problemer enn alle andre faktorer til sammen» (3). Redningsarbeidet ved Åsta-ulykken var preget av tverrfaglighet, innsatspersonellet besto av ca. 600 mennesker fra 11 ulike organisasjoner (1). Det er åpenbart at godt redningssamarbeid er avhengig av tydelig, effektiv og tverrfaglig kommunikasjon, særlig når det dreier seg om pasientens prioritet.

\section{Standardisert tilnærming}

Et felles tverrfaglig flytskjema for katastrofetriage og et system for pasientmerking kan gi mindre forvirring på skadestedet.

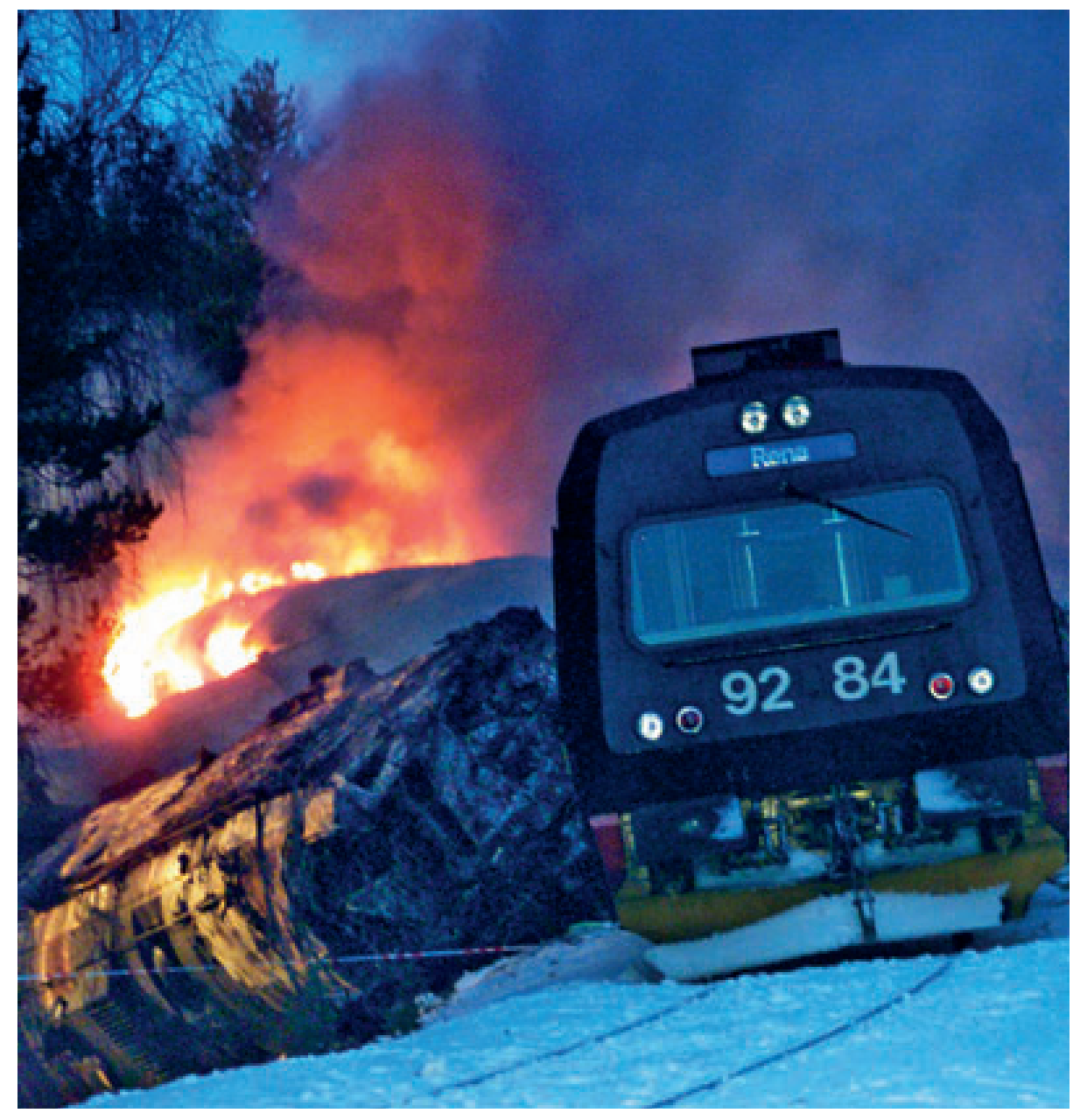

4. januar 2000 kolliderte to tog ved Åsta sør for Rena. Foto SCANPIX
Nasjonale standarder er etterlyst både i USA og Australia $(4,5)$. I en gjennomgang av publisert materiale om katastrofer fant Frykberg \& Tepas en gjennomsnittlig overprioritering på $59 \%$. De avdekket også en lineær sammenheng mellom overprioritering og mortalitet, og påpeker at uhensiktsmessig overforbruk av begrensede ressurser påvirker omsorgen for de hardt skadede (6). Fraværet av et reliabelt, validert og nasjonalt akseptert konsept for katastrofetriage er derfor et alvorlig hull i den norske katastrofeberedskapen.

\section{Tverrfaglig}

\section{akuttmedisinsk samarbeid}

I fravær av en sivil norsk standard for tverrfaglig redningsinnsats har Stiftelsen Norsk Luftambulanse utviklet et konsept for katastrofetriage. Det undervises i dette, og det testes på kurs i Tverrfaglig Akuttmedisinsk Samarbeid (TAS). TAS-kursene er gratis for deltakerne. Siden 1998 har over 15500 mennesker fra forskjellige redningsetater deltatt på mer enn 500 kurs. Tjenestemenn og -kvinner fra politi, brann, bergingstjenester samt helsevesen lærer å gjennomføre katastrofetriage $i$ en simulert storulykke i sitt lokalsamfunn. Erfaringer fra kursene viser at TAS-triage er et presist og brukervennlig konsept for katastrofetriage (7). Det er basert på etablerte konsepter, men videreutviklet med tanke på feltvennlighet under norske forhold $(8,9)$. Mottoet for TAS-triage er «den daglige rutine», og man viderefører etablerte - men forenklede - prosedyrer i det kaotiske redningsarbeidet. Konseptet er industriuavhengig og fritt tilgjengelig for alle interesserte.

\section{Nasjonal standard \\ for katastrofetriage}

Mye av planverket for norsk redningsinnsats utformes av Justis- og politidepartementet, mens den medisinske kompetansen ligger $i$ helsevesenet. Det er derfor av stor betydning at helsearbeidere bistår det ikke-helsefaglige byråkratiet i pasientnære spørsmål. Hvilket triagekonsept som blir fremtidens nasjonale standard, bør bestemmes ut fra et helseoperativt perspektiv. Hvilken modell som blir valgt er uviktig så lenge alle tilskadekomne får optimal omsorg. 
I Stortingsmelding nr. 47, Samhandlingsreformen, understrekes det at bedre samhandling bør være et av helse- og omsorgssektorens viktigste utviklingsområder i tiden fremover (10). Standardisert «sortering» og merking av tilskadekomne kan bedre den livsviktige samhandlingen. En nasjonal standard for katastrofetriage eksisterer ikke. Behovet er åpenbart - særlig når det å feile $\mathrm{i}$ å planlegge er å planlegge $\mathrm{i}$ å feile.

\section{Marius Rehn}

marius.rehn@snla.no

Stiftelsen Norsk Luftambulanse

Postboks 94

1441 Drøbak

og

Akershus universitetssykehus

\section{Hans Morten Lossius}

Stiftelsen Norsk Luftambulanse

og

Universitetet i Bergen

Oppgitte interessekonflikter: Forfatterne er ansatt i Stiftelsen Norsk Luftambulanse (SNLA), som har utviklet og finansiert katastrofetriagekonseptet TAS-triage. TAS-triage er et industriuavhengig triagekonsept, fritt tilgjengelig for alle norske nødetater.

\section{Litteratur}

1. Norges offentlige utredninger. Åsta-ulykken. NOU 2000: 30.

2. Aylwin CJ, Konig TC, Brennan NW et al. Reduction in critical mortality in urban mass casualty incidents: analysis of triage, surge, and resource use after the London bombings on July 7, 2005. Lancet 2006; 368: 2219-25.

3. Simon R, Teperman S. The World Trade Center attack. Lessons for disaster management. Crit Care 2001; 5: 318-20.

4. Armstrong JH, Frykberg ER, Burris DG. Toward a national standard in primary mass casualty triage. Disaster Med Public Health Prep 2008: 2 (suppl 1): S8-10.

5. Nocera A, Garner A. Australian disaster triage: a colour maze in the Tower of Babel. Aust N Z J Surg 1999; 69: 598-602.

6. Frykberg ER, Tepas JJ 3rd. Terrorist bombings. Lessons learned from Belfast to Beirut. Ann Surg 1988; 208: 569-76.

7. Rehn M, Andersen JE, Vigerust T et al. A concept for major incident triage: full-scaled simulation feasibility study. BMC Emerg Med 2010; 10: 17.

8. Advanced Life Support Group, red. Major incident medical management and support, the practical approach at the scene. 2. utg. Plymouth: BMJ Publishing Group, 2002.

9. Hodgetts T, Hall J, Maconochie I et al. Paediatric triage tape. Pre-Hospital Immediate Care 1998; 2: 155-9.

10. St.meld. nr. 47 (2009). Samhandlingsreformen. 